\title{
Upaya Meningkatkan Hasil Belajar IPA Siswa Melalui Model Pembelajaran Kooperatif Tipe Jigsaw Di Kelas VI SDN 57/X Kampung Laut T.A 2020/2021
}

\author{
Dasni \\ SDN 57/X Kampung Laut \\ J1. Taqwa Kampung Laut, Kuala Jambi, Jambi, Indonesia \\ dasni@gmail.com
}

\begin{abstract}
This research is motivated by the low learning outcomes of students. This study aims to describe and obtain information on improving science learning outcomes through the Jigsaw type cooperative learning model. This research is classroom action research consisting of two cycles, each cycle consisting of two meetings. Each meeting consists of four stages, namely planning, implementation, observation, and reflection. The subjects of this study were students of class VI SDN 57/X Kampung Laut, totaling 24 people. This research was conducted in the even semester of the 2020/2021 academic year. Data collection techniques using tests, observations, and documentation. Data were analyzed using percentages. The results of the study show that the Jigsaw type cooperative learning model can improve science learning outcomes for sixth grade students at SDN 57/X Kampung Laut by giving praise.
\end{abstract}

Keywords: Learning outcomes, IPA, Jigsaw

\begin{abstract}
Abstrak
Penelitian ini dilatarbelakangi oleh rendahnya hasil belajar peserta didik. Penelitian ini bertujuan untuk mendeskripsikan dan mendapatkan informasi peningkatan hasil belajar IPA melalui model pembelajaran kooperatif tipe Jigsaw. Penelitian ini merupakan penelitian tindakan kelas yang terdiri dari dua siklus masingmasing siklus terdiri dari dua kali pertemuan. Masing-masing petemuan terdiri dari empat tahapan yaitu perencanaan, pelaksanaan, observasi dan refleksi. Subjek penelitian ini adalah siswa kelas VI SDN 57/X kampung Laut yang berjumlah sebanyak 24 orang. Penelitian ini dilaksanakan pada semseter genap tahun ajaran 2020/2021. Teknik pengumpulan data menggunakan tes, observasi, dan dokumentasi. Data dianalisis menggunakan persentase. Hasl penelitian menunjukkan bahwa melalui model pembelajaran kooperatif tipe Jigsaw dapat meningkatkan hasil bealajar IPA siswa kelas VI SDN 57/X Kampung Laut dengan tindakan pemberian pujian.
\end{abstract}

Kata kunci: Hasil belajar, IPA, Jigsaw

Copyright (c) 2022 Dasni

Corresponding author: Dasni

Email Address: dasni@gmail.com (Jl. Taqwa Kampung Laut, Kuala Jambi, Jambi)

Received 10 January 2022, Accepted 20 January 2022, Published 28 January 2022

\section{PENDAHULUAN}

Pendidikan merupakan suatu kegiatan yang universal dalam kehidupan manusia, bertujuan untuk membentuk peserta didik yang memiliki wawasan luas serta berdaya gunabagi masyarakat. Pendidikan di SD/ sederajat dimaksudkan untuk memberikanbekal kemampuan dasar kepada siswa berupa pengetahuan, keterampilan dan sikap yang bermanfaat bagi diri mereka sendiri sesuai dengan tingkat perkembangannya, serta persiapan untuk melanjutkan ke jenjang yang lebih tinggi. Pendidikan merupakan usaha sadar yang dengan sengaja dirancang untuk mencapai tujuan yang telah ditetapkan. Tujuan tersebut adalah untuk meningkatkan kualitas sumber daya manusia yang berdaya saing dalam percaturan global dewasa ini.

Salah satu masalah yang dihadapi dunia pendidikan kita adalah masalah lemahnya proses pembelajaran. Dalam proses pembelajaran, anak kurang didorong untuk mengembangkan kemampuan 
berpikir. Proses pembelajaran di dalam kelas diarahkan kepada kemampuan anak untuk menghafal informasi, otak anak dipaksa untuk mengingat dan menimbun berbagai informasi tanpa dituntut untuk memahami informasi yang diingatnya dan menghubungkannya dengan kehidupan sehari-hari, sehingga siswa cenderung pasif dalam kegiatan pembelajaran.

Usaha dalam pengembangan kegiatan pendidikan tersebut adalah meningkatkan mutu pendidikan, melengkapi sarana dan prasarana serta mengadakan pelatihan bagi guru. Hal ini diperlukan untuk mengembangkan kemampuan profesional dan membentuk watak serta peradaban bangsa yang bermatabat dalam rangka mencerdaskan kehidupan bangsa. Menurut Slameto (2009:23) dalam kegiatan pembelajaran ada banyak hal yang akan menjadi faktor pendukung sukses atau tidaknya kegiatan pembelajaran yang dilakukan. Di antara faktor-faktor tersebut seperti: latar belakang keluarga, motivasi, kurikulum, metode ataupun strategi belajar, disiplin belajar siswa, kualitas tenaga pendidik, media yang digunakan saat pembelajaran, lingkungan belajar, dan lain-lain. Proses belajar mengajar yang melibatkan guru, siswa, metode atau strategi itu harus dapat saling melengkapi dan bekerjasama secara harmonis. Salah satu mata pelajaran yang diajarkan di SD adalah mata pelajaran IPA. Upaya-upaya peningkatan hasil belajar mata pelajaran IPA dengan menggunakan metode problem solving, memberikan contoh-contoh yang nyata kepada siswa, agar mereka lebih paham dengan materi yang diajarkan oleh guru.

Berdasarkan observasi dan pengalaman mengajar peneliti di SD N Kampung Laut Kabupaten Tanjung Jabung Timur khususnya siswa kelas VI. Pada proses pembelajaran siswa masih kurangmmemahami dalam pelaksanaan pembelajaran di kelas, dan siswa banyak tidak fokus ketika proses pembelajaran berlangsung. Dengan jumlah siswa 24 Orang, 15 Orang perempuan dan 9 orang laki-laki, dengan standar KKM 70 namun nyatanya hanya 10 siswa yang lulus KKM pada ulangan harian dan selebihnya 14 orang tidak tuntas atau tidak lulus KKM. Oleh karena itu, guru dituntut untuk dapat mencari dan memilih model pembelajaran yang tepat sehingga dapat membantu para siswanya memahami dan menguasai kompetensi dasar tersebut dengan baik.

Salah satu model pembelajaran yang dapat membantu guru mencapai tujuan pembelajaran adalah model pembelajaran kooperatif tipeJigsaw. Pembelajaran kooperatif tipe Jigsaw merupakan salah satu bentuk dari model pembelajaran yang dikembangkan untuk mencapai tiga tujuan pembelajaran, yaitu hasil belajar siswa meningkat, penerimaan terhadap keragaman, dan pengembangan keterampilan sosial. Pada model pembelajaran kooperatif tipe Jigsaw, terdapat kelompok asal dan kelompok ahli. Kelompok asal yaitu kelompok induk siswa yang beranggotakan siswa dengan kemampuan, asal dan latar belakang keluarga yang beragam. Kelompok ahli yaitu kelompok induk siswa yang terdiri dari anggota kelompok asal yang berbeda yang ditugaskan untuk mempelajari dan mendalami topik tertentu dan menyelesaikan tugas-tugas yang berhubungan dengan topiknya untuk kemudian dijelaskan kepada anggota kelompok asal (Ibrahim dkk, 2000).

Salah satu syarat agar model pembelajaran ini dapat terlaksana dengan baik adalah siswa harus diberi lembar kegiatan yang berisi sejumlah pertanyaan atau tugas terencana untuk dikerjakan 
bersama-sama dengan anggota kelompoknya.Selama kerja kelompok, tugas anggota kelompok adalah ketuntasan konsep yang disajikan guru dan saling membantu teman kelompok untuk mencapai ketuntasan dalam pembelajaran.Guru tidak banyak mendominasi kelas, tetapi guru bertindak sebagai fasilitator dan koordinator belajar siswa. Berdasarkan uraian di atas, penulis tertarik untuk mangadakan penelitian tindakan kelas (PTK). Dalam penelitian ini penulis memberi judul penelitian yakni "Upaya Meningkatkan Hasil Belajar IPA siswa Melalui Model Pembelajaran Kooperatif tipe Jigsaw di Kelas VI SDN 57/X Kampung Laut T.A 2020/2021”. Penelitian ini bertujuan untuk mengungkapkan informasi dan membahas tentang upaya peningkatan hasil belajar IPA melalui model pembelajaran Jigsaw di kelas VI SDN Kampung Laut.

Belajar yang berhasil harus melalui bermacam aktifitas baik fisik maupun psikis (Supriadi:2001). Pembelajaran harus memberi pengalaman belajar yang melibatkan siswa pada proses. Belajar merupakan sebuah proses perubahan yang terjadi di dalam diri manusia. Perubahan tersebut dapat dilihat dalam bentuk peningkatan kualitas dan kuantitas tingkah laku seperti peningkatan kecakapan, pengetahuan, sikap, kebiasaan, pemahaman, ketrampilan, daya pikir, dan kemampuan-kemampuan yang lain. Pembelajaran akan aktif apabila adanya interaksi antara guru dengan siswa. Agar interaksi tersebut bisa tercipta dengan baik, maka seorang guru harus menjalankan fungsinya sebagai fasilitator yang bertujuan agar interaksi antara guru dengan siswa, maupun siswa dengan siswa. Sehingga dalam proses pembelajaran akan terciptanya suasana belajar yang menyenagkan.

Hasil belajar merupakan tujuan akhir dilaksanakannya kegiatan pembelajaran di sekolah. Hasil belajar dapat ditingkatkan melalui usaha sadar yang dilakukan secara sistematis mengarah kepada perubahan yang positif yang kemudian disebut dengan proses belajar. Akhir dari proses belajar adalah perolehan suatu hasil belajar siswa. Hasil belajar siswa di kelas terkumpul dalam himpunan hasil belajar kelas. Semua hasil belajar tersebut merupakan hasil dari suatu interaksi tindak belajar dan tindak mengajar. Dari sisi guru, tindak mengajar di akhiri dengan proses evaluasi hasil belajar, sedangkan dari sisi siswa, hasil belajar merupakan berakhirnya puncak proses belajar (Dimyati dan Mudjiono, 2009: 3).

Ilmu Pengetahuan Alam adalah mata pelajaran yang erat kaitannya terutama dalam menerima dan mengkomunikasikan berbagai teknologi yang terus berkembang seperti sekarang ini. Mampu menciptakan sumber daya manusia, yang terampil, teliti dan cerdas ke dalam masyarakat maju yang serba modern dengan berkepribadian dan bermoral bangsa yang luhur serta berakhlak mulia. Sehingga perlu menjaga dan meningkatkan mutu hasil belajar siswa pada mata pelajaran tersebut. Menurut Joyce, Weil, \& Showers (1992: 4), "A model of teaching is a plan or pattern that we can use to design face-to-face teaching in classrooms or tutorial settings and to shape instructional materials-including books, films, tapes, computer-mediated programs, and curricula.Bahwa model pembelajaran adalah suatu perencanaan atau pola yang digunakan sebagai pedoman dalam perencanaan pembelajaran di kelas atau pembelajaran dalam tutorial, dan untuk menentukan perangkat-perangkat pembelajaran 
termasuk di dalamnya buku-buku, film, tape, program komputer, dan kurikulum. Pembelajaran kooperatif merupakan sebuah kelompok strategi pengajaran yang melibatkan siswa bekerja secara berkolaborasi untuk mencapai tujuan bersama. Pembelajaran kooperatif muncul dari konsep bahwa siswa akan lebih mudah menemukan dan memahami konsep yang sulit jika mereka saling berdiskusi dengan temannya.

Jigsaw telah dikembangkan dan diujicoba oleh Elliot Aronson dan teman-teman dari Universitas Texas, dan diadopsi oleh Slavin dan teman-teman di Universitas John Hopkins. Jigsaw merupakan salah satu model pembelajaran kooperatif dimana siswa ditempatkan ke dalam tim beranggotakan 5 atau 6 orang untuk mempelajari materi pelajaran yang telah dibagi menjadi beberapa bagian untuk tiap anggota. Model pembelajaran Jigsawmenitikberatkan pada kegiatan inti yaitu pemerolehan konsep. Pemerolehan konsep dalam model pembelajaran Jigsawdilakukan dengan cara pembagian siswa dalam beberapa kelompok dengan anggota kelompok yang heterogen yang disebut sebagai kelompok asal, setiap anggota dalam kelompok asal akan mendapatkan bahan materi yang berbeda-beda, kelompok ini akan dibagi lagi menjadi kelompok baru yang akan membahas bagian materi yang homogen, kelompok ini disebut kelompok ahli. Setiap kelompok ahli berdiskusi dan bekerjasama dengan anggotanya yang berasal dari anggota kelompok asal yang berbeda-beda. Anggota kelompok ahli akan kembali ke kelompok asalnya, mereka harus memahami apa yang telah dipelajari dalam diskusi kelompok ahli, sehingga mereka dapat menjelaskan bagian materi yang telah didapatkan kepada teman kelompok asal (Ibrahim, dkk., 2000).

\section{METODE}

\section{Setting Penelitian}

Penelitian ini dilaksanakan di kelas VI SDN 57/X Kampung Laut Kabupaten Tanjung Jabung Timur. Subjek penelitian ini adalah siswa kelas VI SD N Kampung Laut Kabupaten Tanjung Jabung Timur yang berjumlah 24 siswa dengan komposisi 9 laki - laki dan 15 perempuan. Penelitian ini akan dilaksanakan pada semester dua (II) bulan Maret Tahun Ajaran 2020/2021. Teknik pengumpulan data menggunakan tes, observasi, dan dokumentasi. Data dianalisis menggunakan persentase.

\section{HASIL DAN DISKUSI}

\section{Pra Siklus}

Pra siklsus merupakan kondisi awal peserta didik sebelum peneliti melakukan kegiatan penelitian di dalam kelas, dengan menggunakan pola pembelajaran konvensional. Selanjutnya, berdasarkan hasil data Pra Siklus yang diperoleh, peneliti bersama guru lain melakukan evaluasi mengenai metode/model pembelajaran yang dianggap tepat, sebagai bentuk tindakan perbaikan dari proses pembelajaran. Kegiatan pengambilan data Pra siklus dilakukan di Kelas VI SDN 57/X Kampung Laut dengan jumlah peserta didik 24 orang. Prasiklus di lakukan peneliti dengan cara melaksanakan kegiatan pembelajaran IPA dengan menggunakan metode tanya jawab yang diakhiri 
dengan pelaksanaan tes. Hasil proses pembelajaran terlihat monoton dan berpusat pada guru, tingkat partisipasi peserta didik dalam belajar rendah, kurang temotivasi dalam belajar, banyak peserta didik yang tidak memperhatikan ketika guru menerangkan pelajaran di depan kelas, dan mengobrol bersama temannya. Dampaknya hasil belajar peserta didik juga rendah, ini dibuktikan dari hasil ulangan harian terakhir sebelum metode yang diterapkan dengan nilai tertinggi data selengkapnya, dapat dilihat pada tabel di bawah ini:

Tabel 1. Nilai Ulangan Harian siswa pra siklus

\begin{tabular}{|c|l|c|c|}
\hline \multicolumn{4}{|c|}{ Kesimpulan Hasil Belajar Pra Siklus } \\
\hline No & Keterangan & Frekuensi & Persentase \\
\hline 1 & Tuntas & 10 & $42 \%$ \\
\hline 2 & Tidak Tuntas & 14 & $58 \%$ \\
\hline \multicolumn{2}{|c|}{ Jumlah } & 24 & 100 \\
\hline \multicolumn{2}{|c|}{ Jumlah } & \multicolumn{2}{|c|}{63.75} \\
\hline \multicolumn{2}{|c|}{ Rata-rata } &
\end{tabular}

Dari tabel di atas dapat dijelaskan bahwa sebelum menerapkan Model pembelajaran Jigsaw di peroleh rata-rata hasil belajar peserta didik yaitu 63,75 dengan presentase $42 \%$ atau 10 peserta didik dari 24 Peserta Didik yang tuntas belajar. Hasil tersebut menunjukkan bahwa pada pra siklus secara klasikal peserta didik belum tuntas belajar, karena hanya 10 peserta didik yang memperoleh nilai $\geq 70$ atau hanya sebesar $42 \%$ yang mencapai kriteria ketuntasan minimum (KKM). Sehingga, masih terdapat 14 dari 24 Peserta Didik yang belum tuntas belajar atau sebanyak 48\%. Hasil tersebut lebih kecil dari presentase ketuntasan klasikal dalam proses pembelajaran IPA yang dikehendaki sebesar $80 \%$.

\section{Siklus I}

a. Perencanaan

Pada tahap ini peneliti mempersiapkan perangkat pembelajaran yang terdiri dari silabus, RPP, media card, buku paket, LKS, Instrumen. Lalu menyiapkan dokumen observasi, lembar aktivitas guru, lembar observasi aktivitas peserta didik, panduan wawancara responden siswa, perolehan hasil belajar siswa UH 1 tanpa model. Persiapan yang dilakukan pada perencanaan siklus I adalah Mempersiapkan jadwal penelitian tindakan kelas, merencanakan materi yang akan dilaksanakan pada waktu penelitianagar mengetahui kompetensi dasar yang akan disampaikan kepada siswa dalam pembelajaran, mempersiapkan RPP, mempersiapkan silabus, LKS, instrumen, dan mempersiapkan Modul Pembelajaran.

b. Pelaksanaan

Pelaksanaan kegiatan belajar mengajar untuk siklus I pertemuan satu dilaksanakan pada hari senin tanggal 8 Maret 2021 di Kelas VI dengan jumlah peserta didik 24 Peserta Didik. Dalam hal ini peneliti bertindak sebagai guru. Adapun proses belajar mengajar mengacu pada rencana pelajaran yang telah dipersiapkan. Adapun materi pembelajaran pada siklus satu pertemuan satu yaitu 
perputaran bumi dan akibatnya (Rotasi bumi dan akibatnya).

Pada Kegiatan awal guru mengucapkan salam, mengecek kebersihan kelas. Kemudian guru mendata kehadiran peserta didik secara klasikal lalu mengkondisikan peserta didik untuk memulai pembelajaran dengan mengucapkan bismillah, kemudian guru memberikan motivasi memberikan apersepsi dengan bertanya kepada siswa. Guru menyampaikan informasi tentang kegiatan yang akan dilakukan yaitu materi tentang perputaran bumi dan akibatnya (Rotasi bumi dan akibatnya), guru membimbing siswa dalam pembentukan kelompok, peserta didik dalam setiap kelompok mengamati dengan seksama dan mendiskusikan permasalahan tentang perputaran bumi dan akibatnya (Rotasi bumi dan akibatnya). Siswa melaksanakan strategi yang sesuai dengan permasalahannya tentang materi tersebut. Lalu, siswa megkaji kembali dan mengevaluasi permasalahannya. Guru menceritakan tentang udin, salah satu temannya yang tinggal di daerah lain.

Guru menceritakan bahwa teman-teman udin tinggal di daerah Sumatera Barat, Sulawesi Barat, dan Maluku Utara. Guru menunjukkan peta cerita tentang hal-hal yang dilakukan teman udin. Guru meminta siswa untuk mengamati kegiatan yang ada dalam peta. Kemudian guru meminta untuk mencari perbedaan berdasarkan wilayah waktu dan bagaimana perbedaan tersebut mempengaruhi teman udin. Guru berdiskusi dengan peserta didik untuk membahas pertanyaan tersebut. Guru memeriksa kegiatan diskusi tentang permasalahan tentang perputaran bumi dan akibatnya (Rotasi bumi dan akibatnya) yang dilakukan peserta didik bagaimana berjalannya diskusi dan cara pemecahan masalahnya. Jika masih ada peserta didik atau kelompok yang belum mengerti dengan permasalahannya, guru dapat langsung memberikan bimbingan. Kemudian siswa diminta untuk mempersentasikan hasil diskusi setiap kelompok. Guru memberikan umpan balik positif dan penguatan dalam bentuk lisan, tulisan, isyarat, maupun hadiah terhadap keberhasilan peserta didik.

Pada kegiatan akhir, peserta didik menjawab pertanyaan-pertanyaan yang telah disediakan untuk kegiatan refleksi. Selain itu pada pertemuan pertama siswa dibimbing guru untuk menyimpulkan materi pelajaran yang sudah dipelajari. Guru memberikan motivasi kepada peserta didik yang kurang atau belum berpartisipasi aktif. Kemudian mengajak siswa untuk menyanyikan salah satu lagu daerah. Pada akhir kegiatan guru menutup pelajaran dengan mengucapkan salam.

Pelaksanaan tindakan siklus I pertemuan 2 Pelaksanaan dilaksanakan pada hari Rabu tanggal 10 Maret 2021 Pada pertemuan kedua guru juga melakukan hal yang sama dengan pertemuan yang pertama pada siklus I. Hal ini berguna untuk melihat peningkatan yang terjadi pada siswa. Pada pertemuan kedua guru juga masih melakukan kegiatan belajar mengajar dengan menggunakan model belajar yang sama dengan pertemuan pertama. Pada akhir siklus ini guru memberikan tes untuk melihat peningkatan yang terjadi.

\section{c. Observasi}

Sesuai dengan tujuan peneliti yaitu meningkatkan hasil belajar IPA menggunakan model pembelajaran Jigsaw pada siswa kelas VI SD Negeri 57/X Kampung Laut, maka pengamatan 
tindakan dengan menggunakan instrument sebagai berikut. Hasil belajar diperoleh dari tes yang dilakukan pada setiap akhir siklus. Data yang diperoleh berupa angka mengenai nilai yang diperoleh masing-masing siswa terhadap soal yang dikerjakan setelah diterapkannya metode Jigsaw dalam proses pembelajaran IPA. Hasil belajar siswa pada siklus I sebagai berikut:

Tabel 2. Nilai Ulangan Harian siswa siklus II

\begin{tabular}{|c|l|c|c|}
\hline \multicolumn{4}{|c|}{ Kesimpulan Hasil Belajar Siklus I } \\
\hline No & Keterangan & Frekuensi & Persentase \\
\hline 1 & Tuntas & 18 & $75 \%$ \\
\hline 2 & Tidak Tuntas & 6 & $25 \%$ \\
\hline \multicolumn{2}{|c|}{ Jumlah } & 24 & 100 \\
\hline \multicolumn{2}{|c|}{ Jumlah } & \multicolumn{2}{|c|}{1770} \\
\hline \multicolumn{2}{|c|}{ Rata-rata } & \multicolumn{2}{c|}{} \\
\hline
\end{tabular}

Dari tabel di atas dapat dijelaskan bahwa dengan menerapkan model pembelajaran Jigsaw diperoleh nilai rata-rata hasil belajar peserta didik adalah 73,75 dan ketuntasan belajar mencapai 75\% atau ada 18 peserta didik dari 24 peserta didik sudah tuntas belajar. Hasil tersebut menunjukkan bahwa pada siklus pertama secara klasikal peserta didik belum tuntas belajar, karena peserta didik memperoleh lebih kecil dari persentase ketuntasan yang dikehendaki yaitu di atas $80 \%$. Hal ini disebabkan karena peserta didik masih merasa baru dan belum mengerti apa yang dimaksudkan dan digunakan guru dengan menerapkan model pembelajaran Jigsaw.

d. Refleksi

Kegiatan refleksi dilakukan secara kolaboratif antara praktisi dan guru kelas (observer) pada setiap pembelajaran berakhir, observer yang bertugas pada penelitian ini adalah Yustina Tewo Rauy, S.Pd.SD. Refleksi dilaksanakan pada hari kamis, tanggal 11 maret 2021 kesempatan ini temuan dan hasil pengamatan peneliti dibahas bersama. Refleksi tindakan siklus I ini mencakup refleksi terhadap perencanaan, pelaksanaan, evaluasi, dan hasil yang diperoleh siswa.

Dari hasil paparan data siklus I diketahui bahwa perencanaan pembelajaran IPA dengan menggunakan model pembelajaran Jigsaw, masih terdapat beberapa kekurangan yang harus diperbaiki di siklus II agar tujuan yang diharapkan dapat tercapai dengan maksimal. Sesuai hasil refleksi praktisi (peneliti) dengan guru kelas, maka perencanaan pembelajaran untuk siklus II tidak jauh berbeda dengan perencanaan pada siklus I. Namun yang lebih ditekankan adalah cakupan materi ajar harus disesuaikan dengan alokasi waktu, serta teknik pembelajaran harus disesuaikan dengan lingkungan sekolah dan lingkungan siswa.

Tindakan pelaksanaan model pembelajaran Jigsaw pada pembelajaran tahap siklus I sudah dilakukan dengan baik namun masih banyak kekurangan dan kurang sesuainya tindakan dengan perencanaan yang telah disusun. Berdasarkan hasil pengamatan yang telah dilakukan olehobserver (guru kelas), maka pada siklus I ditemukan hal-hal yaitu peneliti banyak menghabiskan waktu pada 
saat membentuk kelompok dan mengatur kursi karena siswa memilih-milih teman yang satu kelompok dengannya. Siswa sedikit ribut saat melakukan diskusi, hal ini dikarenakan siswa tidak bekerjasama dengan baik dalam berdiskusi kelompok sehingga beberapa siswa merasa dongkol dengan temannya. Peneliti kurang memotivasi siswa yang kurang aktif, hanya terfokus pada siswa yang aktif melakukan diskusi saja. Seharusnya dalam kegiatan inti pembelajaran guru berusaha menciptakan pola interaksi tiga arah (guru-siswa, siswa-guru, siswa-siswa), dan jangan terfokus pada siswa yang aktif dalam pembelajaran saja. Siswa masih belum memahami materi tentang organisasi kehidupan. Siswa masih banyak siswa yang diam saat berdiskusi, dan yang bicara hanya siswa itu-itu saja. Hasil observasi terhadap pelaksanaan dan evaluasi siswa pada siklus I ini menunjukkan bahwa penerapan metode Jigsaw dalam pembelajaran IPAbelum terlaksana dengan maksimal. Hasil tes pertemuan I dan II pada siklus I menunjukkan bahwa masih ada siswa yangbelum paham dan mampu menjelaskan dengan benar dan memecahkan permasalahan sesuai dengan yang diharapkan.

Dari refleksi pada siklus I, disimpulkan bahwa tujuan pembelajaran yang diharapkan pada siklus I belum tercapai dengan baik. Dengan demikian, penelitian peningkatan hasil belajar IPAmelalui metode Jigsaw peneliti lanjutkan pada siklus II dengan memperhatikan kendala-kendala yang ditemui pada siklus I. Kendala-kendala yang ditemui pada siklus I akan diperbaiki pada siklus II.

\section{Siklus II}

a. Perencanaan

Pada siklus II hampir sama dengan perencanaan pada siklus I. Pelaksanaan tindakan kelas siklus II mengacu pada hasil refleksi pada penelitian tindakan kelas siklus I. Kendala yang ditemui pada pelaksanaan tindakan kelas siklus I diupayakan untuk dapat diantisipasi, agar tidak terjadi kendala yang sama pada siklus II. Berdasarkan refleksi pada siklus I, peneliti merancang tindakan yang akan dilaksanakan pada siklus II yang meliputi: 1) Peneliti bersama guru menyusun rencana pelaksanaan pembelajaran (RPP) tentang Kompetensi Dasar yang harus dicapai dengan menggunakan model pembelajaran Jigsaw. Rencana pelaksanaan pembelajaran (RPP) disusun oleh peneliti dengan pertimbangan dari dosen pembimbing dan guru yang bersangkutan. 2) Mempersiapkanbahan ajar pembelajaran yang akandiajarkan dalam setiap kali pelaksanaan tindakan, seperti buku paket, modul, lembar kerja siswa, serta lembar evaluasi yang digunakan pada akhir siklus. 3) Menyiapkan beberapa instrument penelitian seperti lembar pengamatan siswa dan guru. 4) Melaksanakan pembelajaran IPA dengan model pembelajaran Jigsaw. 5) Memastikan guru memberikan penjelasan mengenai kegiatan pembelajaran sesuai dengan rencana yang dibuat yaitu sebelum kegiatan diskusi. Guru membimbing dan mengarahkan siswa dalam kegiatan pembelajaran, agar berjalan dengan baik. 6) Pada saat kegiatan tanya jawab antar kelompok, guru memberikan motivasi kepada siswa agar berani mempersentasikan hasil diskusi. Guru selalu memberikan peluang bagi siswa yang belum pernah mempersentasikan hasil diskusi. Jika ada jawaban yang salah maka guru memberikan penjelasan mengenai jawaban yang benar.

b. Pelaksanaan 
Pelaksanaan tindakan siklus II pertemuan 1, dilaksanakan pada hari Senin tanggal 15 Maret 2021. Kegiatan awal. Guru mengucapkan salam, mengecek kebersihan kelas, guru mendata kehadiran peserta didik secara klasikal lalu mengkodisikan peserta didik untuk memulai pembelajaran, Motivasi, Guru memberikan apersepsi dengan bertanya kepada siswa, Pemberian acuan KD. Pada kegiatan inti Guru menyampaikan informasi tentang kegiatan yang akan dilakukan yaitu melakukan pengamatan untuk mendeskripsikan Perbedaan Musim, guru membimbing siswa dalam pembentukan kelompok, peserta didik dalam setiap kelompok mengamati dengan seksama. Guru membagi topik pembelajaran sesuai dengan kelompok belajar yang terbentuk.

Guru membagikan 4-5 tema pembelajaran yang akan dibahas dimasing-masing kelompok, dan semua kelompok mendapat pembagian tema yang berbeda. Guru meminta masing-masing kelompok untuk menganalisis dan memahami secara bersama-sama dikelompoknya masing-masing atau disebut dikelompok awal atau kelompok besar. Siswa diminta untuk mencari solusi dari permasalahannya pada materi tersebut. Lalu kelompok melaksanakan strategi yang berhubungan dengan materi tersebut. Kelompok mengkaji kembali dan mengevaluasi permasalahannya. Kemudian setelah itu, guru meminta salah satu kelompok untuk maju untuk mempresentasikan hasil diskusi dikelompoknya mengenai keragaman pada Perbedaan Musim dengan diperhatikan oleh kelompok lain guna sebagai evaluator teman sejawat. Guru memberikan pujian kepada peserta didik yang aktif bertanaya dan memberikan pendapat pada diskusi. Diakhir pembelajaran guru bersama siswa menyimpulkan materi pelajaran dan diberi pekerjaan rumah.

Pada kegiatan penutup guru memberikan penguatan dari hasil diskusi, kemudian menginformasikan materi untuk pertemuan berikutnya. Guru bersama siswa menyimpulkan materi pelajaran dan memberikan tugas. Diakhir pembelajaran guru mengucapkan salam dan siswa berdoa setelah belajar. Pada pertemuan kedua guru juga melakukan hal yang sama dengan pertemuan yang pertama pada siklus II. Hal ini berguna untuk melihat peningkatan yang terjadi pada siswa. Pada pertemuan kedua guru juga masih melakukan kegiatan belajar mengajar dengan menggunakan metode belajar yang sama dengan pertemuan pertama. Pada akhir siklus ini guru memberikan tes untuk melihat peningkatan yang terjadi.

c. Observasi

Sesuai dengan tujuan peneliti yaitu meningkatkan hasil belajar IPA menggunakan model pembelajaran Jigsaw pada siswa kelas VI SD NegaeriKampung Laut, maka pengamatan tindakan dengan menggunakan instrument sebagai berikut. Hasil belajar diperoleh dari tes yang dilakukan pada setiap akhir siklus. Data yang diperoleh berupa angka mengenai nilai yang diperoleh masing-masing siswa terhadap soal yang dikerjakan setelah diterapkannya metode Jigsaw dalam proses pembelajaran IPA. Hasil belajar siswa pada siklus II sebagai berikut: 
Tabel 3. Nilai Ulangan Harian siswa siklus II

\begin{tabular}{|c|c|c|c|}
\hline \multicolumn{4}{|c|}{ Kesimpulan Hasil Belajar Pra Siklus } \\
\hline No & Keterangan & Frekuensi & Persentase \\
\hline 1 & Tuntas & 22 & $92 \%$ \\
\hline 2 & Tidak Tuntas & 2 & $8 \%$ \\
\hline \multicolumn{2}{|c|}{ Jumlah } & 24 & 100 \\
\hline \multicolumn{2}{|c|}{ Jumlah } & \multicolumn{2}{|c|}{86.25} \\
\hline \multicolumn{2}{|c|}{ Rata-rata } &
\end{tabular}

Dari tabel di atas dapat dijelaskan bahwa dengan menerapkan model pembelajaran Jigsaw diperoleh nilai rata-rata hasil belajar peserta didik 86,25 dan ketuntasan belajar mencapai $92 \%$ atau ada 22 dari 24 peserta didik sudah tuntas belajar. Hasil tersebut menunjukkan bahwa pada siklus kedua secara klasikal peserta didik sudah tuntas belajar, karena peserta didik yang memperoleh nilai $\geq 70$ lebih besar dari persentase ketuntasan yang dikehendaki yaitu di atas $80 \%$. Maka hasil belajar siswa sudah mencapai ketuntasan belajar yang sudah ditargetkan. Oleh karena itu tidak dilakukan lagi tindakan siklus berikutnya.

d. Refleksi

Berdasarkan tabel di atas dapat dijelaskan bahwa dengan menerapkan model pembelajaran Jigsaw diperoleh nilai rata-rata hasil belajar peserta didik 86,25 dan ketuntasan belajar mencapai 92\% atau ada 22 dari 24 peserta didik sudah tuntas belajar. Hasil tersebut menunjukkan bahwa pada siklus kedua secara klasikal peserta didik sudah tuntas belajar, karena peserta didik yang memperoleh nilai $\geq$ 70 lebih besar dari persentase ketuntasan yang dikehendaki yaitu di atas 80\%. Maka hasil belajar siswa sudah mencapai ketuntasan belajar yang sudah ditargetkan. Oleh karena itu tidak dilakukan lagi tindakan siklus berikutnya.

\section{Diskusi}

Dari temuan yang didapat pada siklus pertama berkaitan dengan hasil belajar siswa mengenai pembelajaran IPA setelah menggunakan model pembelajaran jigsaw yang terdiri dari dua kali pertemuan. Berdsarkan aspek-aspek yang di amati ternyata hasil pembelajaran ini belum mencapai persentase rata-rata nilai KKM yang telah ditentukan. Pada siklus I mencapai nilai-nilai rata persentase hasil belajar peserta didik adalah 73,75 dan ketuntasan belajar mencapai $75 \%$ atau 18 peserta didik sudah tuntas belajar. Hasil tersebut menunjukkan bahwa pada siklus pertama secara klasikal peserta didik belum tuntas belajar, karena peserta didik yang memperoleh nilai $\geq 70$ hanya sebesar $75 \%$ lebih kecil dari persentase ketuntasan yang diharapkan yaitu di atas $80 \%$. Pencapaian nilai hail belajar pada siklus I ini dapat disebabkan oleh faktor penerapan model pembelajaran dan belum adanya tindakan yang diberikan.

Dari temuan pada siklus ke dua yang berkaitan dnegan hasil belajar siswa pada pembelajaran IPA setelah menggunakan model pembelajaran Jigsaw yang terdiri dari dua kali pertemuan juga sesuai dengan aspek yang di amati ternyata bahwa hasilbelajar siswa pada siklus ke II ini sudah hampir 
seluruh siswa telah mncapai standar KKM yang telah ditentukan. Dengan demikian pancapaian nilainilai rata-rata hasil belajar pada siklus II ini baik itu pertemuan pertama maupun kedua sudah dapat mencapai nilai-nilai rata KKM yang ditunjukkan dengan persentase nilai-nilai akhir hasil belajar sebesar $92 \%$. Lebih jelasnya dapat dilihat pada grafik dibawah ini:

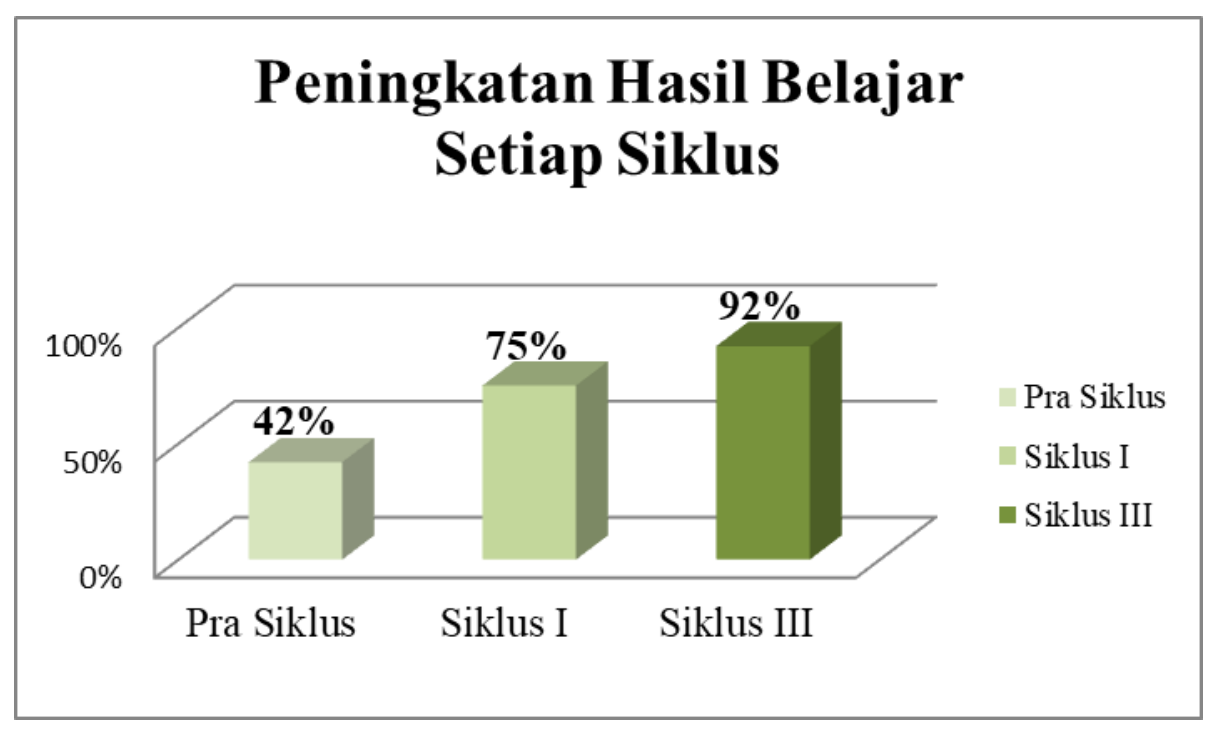

Gambar 1. Peningkatan Hasil Belajar Setiap Siklus

\section{KESIMPULAN}

Berdasarkan hasil penelitian yang telah dilakukan selama dua siklus, hasil seluruh pembahasan serta analisis yang telah dilakukan dapat disimpulkan bahwa penggunaan model pembelajaran Jigsaw pembelajaran mata pelajaran IPA yang dapat meningkatkan hasil belajar siswa Kelas VI SD Negeri Kampung Laut 2020/2021. Hal tersebut dapat dilihat dari peningkatan kemampuan siswa pada siklus I dan siklus II, yaitu hasil belajar siswa pada siklus I, kemampuan siswa dalam mendeskripsikan materi yang dipelajari melalui diskusi kelompok dan menggunakan model pembelajaran kooperatif tipe Jigsaw memperoleh nilai rata-rata yaitu 73,75 (rata-rata kelas) dan pada siklus II, nilai rata-rata hasil belajar siswa 86,25. Selain itu hal ini menunjukkan hasil pembelajaran siswa pada setiap siklus mengalami peningkatan. Dengan demikian, model pembelajaran Jigsaw dapat menjadikan siswa merasa lebih mudah untuk memahami materi yang disampaikan guru.

\section{UCAPAN TERIMA KASIH}

Ucapan terima kasih sangat layak disampaikan untuk semua pihak yang telah membantu dalam pengerjaan artikel ini. Baik teman, dosen, kakak, dan yang lainnya. Artikel ini dapat dibuat karena adanya bantuan mereka. Semoga artikel ini dapat bermanfaaat untuk banyak pihak.

\section{REFERENSI}

Arikunto, S. 2007. Dasar-Dasar Evaluasi Pendidikan (Edisi Revisi). Bumi Aksara, Jakarta. Arikunto, dkk. 2006. Penelitian Tindakan Kelas. Bumi Aksara, Jakarta. 
Arikunto, S. 2001. Prosedur Penelitian Suatu Pendekatan Praktek (Edisi Revisi). Bumi Aksara, Jakarta.

Depdiknas. 2004. Keputusan Kepala Dinas Pendidikan Propinsi Kalimantan Selatan tentang Pedoman penyelenggaraan Ujian Akhir Nasional bagi Sekolah Madrasah Tahun Pelajaran 2003/2004. Pemerintah Propinsi Kalimantan Selatan.

Djamarah \& Zain. 2006. Strategi Belajar Mengajar. Rineka Cipta, Jakarta.

Ibrahim, M., Fida, R., Mohamad, N., \& Ismono. 2000. Pembelajaran Kooperatif. University Press, Surabaya.

Marini. 2005. Implementasi Model Jigsaw Dalam Pembelajaran Konsep Laju Reaksi DiKelas II SMA Negeri 5 Banjarmasin. Skripsi Program Strata-1 FKIP UNLAM Banjarmasin. Banjarmasin (tidak dipublikasikan).

Ratumanan \& Laurens. 2003. Evaluasi Hasil Belajar. UNESA, Surabaya.

Sudjana, N. 1995.Penilaian Hasil Proses Belajar Mengajar. PT Remaja Rosdakarya, Bandung.

Sudrajat, Akhmad. 2006. Pendekatan Pembelajaran. http://akhmadsudrajat. Wordpress.com.

Susilo, H., H. Chotimah \& Y.D. Sari. 2008. Penelilitian Tindakan Kelas Sebagai Sarana Pengembangan Keprofesionalan Guru dan Calon Guru. Bayumedia, Malang.

Trianto. 2007. Model-model Pembelajaran Inovatif Berorientasi Konstruktivistik. Prestasi Pustaka, Jakarta. 